\title{
Effects of IFRS 16 on Key Financial Ratios of Spanish Companies
}

\author{
CONSTANCIO ZAMORA-RAMÍREZ a , JOSÉ MORALES-DÍAZ ${ }^{\text {b }}$ \\ a Universidad de Sevilla, Facultad de Ciencias Económicas y Empresariales, Calle Ramón y Cajal 1, \\ 41018 Sevilla, España. E-mail: constancio@us.es \\ ${ }^{b}$ Instituto de Estudios Bursátiles (IEB), Calle Alfonso XI, 6, 28014 Madrid, España. E-mail: \\ jose.morales@claustro-ieb.es
}

\begin{abstract}
In this paper, we perform an empirical analysis in order to estimate the adoption effect of the new lease accounting standard (IFRS 16) has had on the financial statements of quoted Spanish companies. Previous literature has not considered the final version of the new standard as it had not yet been issued. In this sense, our methodology design is more consistent with the final standard as regards aspects such as lease term, discount rate, and how lease asset and liability are measured. The adoption of IFRS 16 will have a significant impact on the financial statements of Spanish companies; in fact, it will have an even greater impact than on European firms in those sectors most affected, and said impact will also be greater than that demonstrated in previous literature. There will be an important impact on balance sheet: total assets and liabilities will increase, involving an increase in leverage ratios. Interest coverage ratio will experience an important decrease. The effects will be higher in those sectors with higher lease relative volume, such as retail, hotels, professional services and the media. As in previous studies, we do not find consistent results in relation to profitability. This paper will be of use to analysts since it improves the methodology for estimating the impact of lease capitalization.
\end{abstract}

Keywords: IFRS 16, Lease Accounting, Financial Ratios, Impact Assessment.

\section{Los efectos de la IFRS 16 en ratios financieros clave de empresas españolas}

\section{RESUMEN}

En este trabajo se lleva a cabo un análisis empírico para estimar el efecto de la nueva norma contable de arrendamientos (NIIF 16) en los estados financieros de las empresas españolas. La literatura previa sobre el impacto de la capitalización de los arrendamientos operativos se ha desarrollado sin considerar la versión final de dicha norma (debido a que aún no se había emitido). En este sentido, nuestras asunciones son más consistentes con la versión final de la norma en aspectos como el plazo del arrendamiento, el tipo de descuento o cómo se valoran el activo y pasivo por arrendamiento. La adopción de la NIIF 16 tendrá un impacto significativo en los estados financieros de las firmas españolas, incluso mayor que el impacto en las empresas europeas en los sectores más afectados y mayor al impacto observado por la literatura anterior. Se espera un importante impacto en balance a consecuencia del incremento en activos y pasivos, dando lugar a un incremento en los ratios de apalancamiento. El ratio de cobertura de intereses muestra un descenso importante. Estos efectos son mayores en empresas de mayor uso relativo del arrendamiento operativo tales como comercio al por menor, hoteles, servicios profesionales y media. Finalmente, al igual que en análisis previos, no encontramos unos resultados consistentes respecto a la rentabilidad. Nuestro estudio puede ayudar a los analistas debido a que mejora la metodología para la estimación del impacto de la capitalización de los arrendamientos.

Palabras clave: IFRS 16, contabilidad de arrendamientos, ratios financieros, valoración de impacto.

JEL Classification : M41, G32

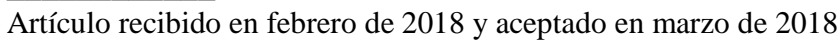

Artículo disponible en versión electrónica en la página www.revista-eea.net, ref. ə-36207 


\section{INTRODUCTION}

In January 2016, the International Accounting Standards Board (IASB) issued a new standard for lease accounting: International Financial Reporting Standard 16 (IFRS 16) that will apply to annual reporting periods beginning on or after 1st January 2019. Within the USGAAP context, the Financial Accounting Standards Board (FASB) issued an equivalent standard: Accounting Standards Codification Topic 842 (ASC Topic 842) with a similar mandatory application date.

The current lease accounting model (i.e. the model currently being applied, prior to said IFRS 16/Topic 842 adoption) was introduced as early as 1976 by SFAS $^{1} 13$ "Accounting for Leases" (now Accounting Standard Codification Topic 840) (see FASB, 1976). Within the IFRS context, the same model was adopted by IAS $^{2} 17$ in 1994 by the former International Accounting Standards Committee (IASC). Both SFAS 13 and IAS 17 standards establish two different measurement principles for leases, depending on whether the lease in question is a finance lease or an operating lease. As far as the lessee is concerned, in operating leases only a lease expense is recognized, while in finance leases the leased good is recognized on the asset side and a debt recognized on the liability side.

This SFAS 13/IAS 17 model has been much criticized. Academics (Reither, 1998; Duke et al., 2009); practitioners (AICPA, 1994); and users (Vivien Beattie, Goodacre, \& Thomson, 2006) all argue that entities are not recognizing all lease obligations and assets on their balance sheets, which leads to a lack of comparability. Moreover, companies (lessees) structure lease contracts so that they can be kept off-balance sheet, i.e. so that they may be considered as operating leases (Abdel-Khalik, 1981; Duke et al., 2009; Beatty et al., 2010; Bryan et al,. 2010; Dechow et al., 2011; Cornaggia et al., 2011). Empirical research shows that operating leases are perceived by investors as liabilities, and are incorporated into debt ratings and bond yields (Dhaliwal, Lee, \& Neamtiu, 2011).

In 2006, taking these arguments into consideration, the FASB and IASB initiated a joint project regarding a new lease standard. They concluded that a lease contract immediately generates for the lessee an asset (a right-of-use), as well as a liability (future lease payments), and that almost all lease operations should therefore be capitalized (not only current finance leases). The first proposal for the new model (i.e. the first draft standard) was issued by the IASB in 2010, and a revised draft was subsequently issued in $2013^{3}$. Under these new

\footnotetext{
${ }^{1}$ SFAS: Statement of Financial Accounting Standards

${ }^{2}$ IAS: International Accounting Standard.

${ }^{3}$ The FASB also issued a first draft in 2010 and a revised draft in 2013, since this was a joint project. Prior to issuing the Exposure Drafts, they issued a Discussion Paper in 2009 ('Leases. Preliminary
} 
standards (IFRS 16/Topic 842), few lease contracts will remain off-balance sheet from the lessee perspective. This will have an important effect on an entity's financial statements, since new assets and liabilities will be recognized and the profit and loss effect will differ.

Several studies have analyzed the possible effect that capitalization of the operating leases maintained by companies could have on balance sheet, solvency and profitability ratios: Bennett \& Bradbury, 2003; Duke, Hsieh, \& Su, 2009; Durocher, 2008; Fitó, Moya, \& Orgaz, 2013; Fülbier, Silva, \& Pferdehirt, 2008; Goodacre, 2003; Grossman \& Grossman, 2010; Imhoff Jr. \& Lipe, 1991, 1997; Mulford \& Gram, 2007; Singh, 2012. However, these studies were conducted before the final version of IFRS 16/Topic 842 was issued, and therefore there were differences compared to the final version of the standards in aspects such as the estimation of future lease payments and discount rates (see Morales-Díaz \& Zamora-Ramírez, 2018).

Morales-Díaz \& Zamora-Ramírez (2018) have proposed a new methodology for analyzing the effect of operating lease capitalization under the IFRS 16 final version. Their two main contributions are:

1) Instead of using disclosed future minimum lease payments to calculate the amount of the new lease liability - as previous authors do - they estimate lease payments while considering current lease expense and an average contract life, using information disclosed by certain companies along with information obtained directly from other companies by the authors.

2) The discount rate to be used for each company is calculated considering the company's rating and sector, and the recovery rate from the collateral.

Thanks to these contributions, a more precise methodology has been developed for the estimation of the effect of IFRS 16 on a given company, sector, country or group of countries. This methodology is further improved in our study since assets that emerge from lease capitalization may be calculated more precisely.

Conversely, few papers have studied the effect of capitalizing operating leases on Spanish companies: Pardo F., Giner, \& Cancho, (2015); Fitó, Moya, \& Orgaz, (2013). For this reason, and taking into consideration the methodology of Morales-Díaz \& Zamora-Ramírez (2018), the purpose of this paper is to analyze the impact of lease capitalization on key financial ratios of Spanish companies, determining which sectors may be most affected. More specifically, we study the effects on balance sheet, leverage, profitability and solvency ratios.

We select a sample of 101 quoted Spanish companies, and estimate the balance sheet and profit and loss impact following the final model included in IFRS 16.

Views'). 
This study contributes to previous literature by considering the final version of IFRS 16 and by applying a more precise methodology for estimating its impact on Spanish companies, thus enabling us to detect which sectors in this region are more sensitive to IFRS 16 adoption. Sectors with high volumes of operating leases that are currently not recognized on the balance sheet (and for which a greater impact is more probable) are retail (real estate leases); airlines (aircraft leases); hotels (hotel leases); and telecommunications (networks and other assets). However, the effect on different sectors varies according to the region or country in question (Barone, Birt, \& Moya, 2014; Morales-Díaz \& Zamora-Ramírez, 2018) which is the reason behind our study.

Within the next couple of years, it will be possible to analyze the real effects of IFRS 16 since by then companies will have applied this standard on their financial statements. In this sense, the estimation of IFRS 16 effects will not be necessary. Nonetheless, the methodology applied in this paper may be useful for analysts and other financial statement users to estimate said effects on a company or group of companies that have not yet adopted the IFRS 16 model (because local accounting standards have not adopted this capitalization model or a firm is going to adopt IFRS for the first time, for example).

The remainder of the paper is organized as follows: Section 2 introduces the main changes that IFRS 16 will bring in relation to the current lease accounting model. In Section 3 we include a literature review, and the development of the hypothesis. The methodology applied to our empirical research is explained in Section 4, while in Section 5 we describe the results of our research. Finally, our conclusions are contained in Section 6.

\section{THE PRINCIPAL CHANGES OF IFRS 16 FOR LESSEES}

The most important change contained in IFRS 16 in comparison to IAS 17 concerns the new accounting model that is to be applied by lessees. The model essentially remains the same regarding lessors.

As previously mentioned, under IAS 17, lessees (as well as lessors) should classify all lease agreements either as operating or finance leases. In operating leases, the lessee only recognizes a lease expense while in finance leases, the lessee recognizes the leased asset and a liability.

In the case of lessees, IFRS 16 does not distinguish between operating and finance leases. When an entity enters into a lease contract as a lessee, in almost all cases it will have to recognize a right-of-use (asset) and a debt (lease liability) ${ }^{4}$. The lease liability is initially measured as the present value of future lease payments during the lease term. Right-of-use is initially measured as an

\footnotetext{
${ }^{4}$ There are voluntary exceptions for short-term leases (leases with a term equal to or less than one year), and for leases of low-value assets (value when new approximately USD 5,000).
} 
amount equal to the liability plus other concepts such as the lessee's initial direct costs; prepayments made to the lessor; estimated costs of restoration; removal and dismantling; and less any lease incentives received from the lessor. Two important details of the model are as follows:

1) The lease term does not only include the non-cancellable period. It also includes any additional period covered by an extension option in favor of the lessee if it is "reasonably certain" that said option will be exercised. It also includes any additional period covered by the cancelation option in favor of the lessee if it is "reasonably certain" that said option will not be exercised.

2) The discount rate to be used for calculating the present value of the lease liability is the "interest rate implicit in the lease". In many cases, however, it will be difficult to obtain this rate for lessees as there will not be sufficient information regarding the fair value of the underlying asset, the residual value or the direct costs for the lessor. In those cases where the implicit rate "cannot be readily determined" (IFRS 16.26) - which we understand will be most of cases - a lessee may use what IFRS 16 calls the "lessee's incremental borrowing rate". This is defined as "the rate of interest that a lessee would have to pay to borrow over a similar term, and with a similar security, the funds necessary to obtain an asset of a similar value to the right-of-use asset in a similar economic environment”. IFRS 16 states that the lessee's incremental borrowing rate should account for the following aspects (IFRS 16, BC161): moment in time; lease maturity; the economic environment in which the transaction occurs; the lessee's credit quality; and the nature and quality of the collateral.

With regard to the subsequent measurement of the lease liability, entities should accrue interest using the discount rate determined at lease commencement (provided that a reassessment and a change in the discount rate have not occurred), and reduce lease liability by payments made. Right-of-use is subsequently amortized following IAS 16 principles, and impaired following IAS 36. The revaluation fair value model included in IAS 16 and IAS 40 can also be applied in certain cases for the subsequent measurement of the right-of-use. According to IFRS 16.34, if a lessee applies the IAS 40 fair value model to its investment property, the lessee shall also apply that same fair value model to right-of-use assets that meet the IAS 40 definition of investment property. If right-of-use assets relate to a class of property, plant and equipment to which the lessee applies the IAS 16 revaluation model, a lessee may elect to apply that revaluation model to all right-of-use assets relating to said class of property, plant and equipment (IFRS 16.35).

In certain cases, lease liability should be remeasured during lease life. The difference between previous liability and new liability is recognized against the 
right-of-use, unless the carrying amount of the right-of-use is reduced to zero and there is a further reduction in the measurement of the lease liability, in which case any remaining amount is recognized in the profit and loss account (see IFRS 16.39).

The liability is remeasured by discounting new estimated cash flows using the initial discount rate if there is a change in the amounts expected to be payable under a residual value guarantee, or if there is change in future lease payments resulting from a change in an index or a rate used to determine said payments, such as a change to reflect changes in market rental rates following a market rent review (see IFRS 16.42), for example.

The liability is remeasured by discounting new estimated cash flows using a revised discount rate if there is a change in the lease term, or if there is a change in the assessment of an option to purchase the underlying asset (see IFRS 16.40).

Finally, there are several differences between the IFRS 16 and Topic 842 models. Under IFRS 16, there is a single accounting model for all capitalized leases, as seen above. Under Topic 842, there are two accounting models depending on whether the lease is an operating lease or a finance lease. In the case of an operating lease, expense recognition is made on a linear basis while for a finance lease, expense recognition is made as in IFRS 16. Another relevant difference is that under US GAAP, the voluntary exception for low-value assets does not apply.

\section{LITERATURE REVIEW AND HYPOTHESIS DEVELOPMENT}

The most recent relevant studies regarding an ex-ante impact analysis of lease capitalization (encompassing the period from 2007 to 2016) are those by Mulford \& Gram (2007); Durocher (2008); Fülbier et al. (2008); Duke et al. (2009); Singh (2012); Grossman \& Grossman (2010); Bryan et al. (2010); Fitó et al. (2013); Wong \& Joshi (2015) and Pardo et al. (2015). The empirical evidence of these studies (and other studies issued prior to 2007) generally shows that operating leases result in off-balance sheet financing, earning enhancement and improvement in ratios such as debt to equity (leverage) or ROA. However, quantitative results differ depending on factors such as the sample used, sector, geographical area, etc.

We essentially find two methodologies for capitalizing off-balance sheet leases in the accounting literature: the constructive method and the factor method. In different ways, both methodologies estimate how balance sheet and profit and loss accounts would change if operating leases had been recognized in the balance sheet. 
- The constructive method was first developed by Imhoff Jr. \& Lipe (1991, 1997). It uses the information that companies disclose in the operating leases note (or future commitments note) included in their financial statements. Companies disclose total future minimum lease payments under non-cancellable operating leases for each of the following periods: no later than one year; later than one year; not later than five years; later than five years (see IAS 17.35). Under US GAAP (see ASC 840, 50.2), payments from year one to year five are generally disclosed per year. This information is used to reconstruct the balance sheet and the profit and loss account. Certain assumptions should be considered, such as total lease life; payments structure (from year one to year five if aggregated, and beyond year five); and the discount rate or tax rate.

- The factor method is widely used by rating agencies (see Moody's (2015)) to estimate entities' debt that arises from off-balance sheet leases. It basically consists of multiplying current lease expense by a certain multiple, which differs according to sector. The result is an estimation of the present value of the total future minimum lease payments. This method is less used in the accounting literature.

Mulford \& Gram (2007) focus on retail companies in the US because of their significant reliance on leased facilities such as stores and warehouses” (Mulford \& Gram, 2007). They use a sample of 19 companies and they capitalize leases for the fiscal year 2006 to analyze the impact on several different ratios and metrics (i.e. they recalculate the 2006 result and the final 2006 balance sheet starting from 2005). Lease future payments are taken from financial statement disclosures (as per the constructive method). In relation to balance sheet structure, they find that total assets have a median increase of $14.6 \%$; total liabilities increase by 26.4\%; and the Liability/Equity ratio increases by $265.1 \%$ (in absolute terms). Additionally, they find that EBITDA has a median increase of $22.5 \%$; income from continuing operations decreases by $5.3 \%$; and earnings per share also decrease by $5.3 \%$. ROA decreases by $1.7 \%$ in absolute terms $(15.5 \%$ in relative terms), and ROE decreases by $0.6 \%$ ( $4.8 \%$ in relative terms). Other ratios analyzed include EBITDA/Interests (a decrease of $46.3 \%$ in absolute terms); OCF (Operating Cash Flow)/Interests (a decrease of $38.4 \%$ in absolute terms); OCF/CP (LTD+Capital Leases) (a decrease of 58.5\% in absolute terms); as well as operating cash flow (an increase of $22.9 \%$ in absolute terms) and other metrics. According to the authors, excluding operating leases from the balance sheet causes a material distortion of the company's financial. This distortion is further seen in understated EBITDA and overstated income from continuing operations. Furthermore, key cash flow metrics are understated by the exclusion of operating leases (Mulford \& Gram, 2007). 
Durocher (2008) uses a sample that includes the 100 largest Canadian quoted companies for years 2002 and 2003 (from all sectors). He finds that if leases are capitalized, Canadian companies will report additional assets and liabilities, which would in turn affect their financial strength indicators. After lease capitalization, the $\mathrm{D} / \mathrm{A}$ (Debt/Assets) ratio increases by $2.66 \%$ (4.02\% in relative terms); current ratio decreases by 0.065 (4.74\% in relative terms); ROA increases by $0.03 \%(0.72 \%$ in relative terms); ROE decreases by $0.73 \%$ (6.64\% in relative terms); and EPS decreases by 0.455 ( $0.03 \%$ in relative terms). Sectors with higher differences in the D/A ratio are the Merchandising and lodging sectors (an increase of $6.6 \%$ in absolute terms and $11.57 \%$ in relative terms), and the sector demonstrating a higher ROA difference is industrial products (with a decrease of $2.3 \%$ in absolute terms).

Fülbier et al. (2008) use a sample of 90 companies belonging to the three major German indices: DAX 30, MDAX and SDAX. They collect data from consolidated financial statements for years 2003 and 2004, and investigate the capitalization impact on key financial ratios. Similarly, to previous studies, lease future payments are taken from financial statement disclosures (the constructive method). However, they contrast their results with an alternative methodology used by Standard \& Poor's which applies the factor method. Fülbier et al., analyze thirteen different ratios including Debt/Equity (D/E); Earnings per Share (EPS); ROA and ROE, etc. They observe a significant capitalization impact for a considerable number of companies in general, and for certain industry groups (fashion and retail). Changes in financial ratios occur primarily for balance sheet relationships, but they observe minor effects for profitability ratios and valuation multiples.

About the balance sheet, total liabilities increase by $17.3 \%$ (median); noncurrent assets increase by $8.5 \%$ (median); and $\mathrm{D} / \mathrm{E}$ increases by a median of $16.1 \%$ in absolute terms ( $8.0 \%$ in relative terms). Conversely, EBIT increases by $2.9 \%$ (median), and ratios such as EPS, ROA, and ROE do change at a minimum percentage. They also conclude that the factor method can supply comparable results in a low-interest environment and when a firm is capitalizing comparatively short-term lease contracts.

Duke et al. (2009) select a sample of 366 US companies on the S\&P index (all companies except for utility and banking industries), and use the constructive method. They find that by not capitalizing leases, firms on average avoided reporting USD 582.04 million of lease liabilities, which is $11.13 \%$ of their total reported liabilities (with the average reaching 34.24\% for the 91 firms in the top quartile). Firms also benefit from an improvement in retained earnings (USD 131.79 million on average) and net income (USD 21.99 million on average for 215 firms). Duke et al., find that if leases are capitalized, the D/E ratio would increase by 0.40 in absolute terms (13\% in relative terms). ROA would decrease 
by $0.47 \%$ in absolute terms for the "negative income group" (8.26\%), and increase by $0.11 \%$ in absolute terms for the "positive income group" (3.49\%). Current ratio would decrease by 0.14 in absolute terms for the "negative income group" (6.89\%), and decrease by 0.11 for the "positive income group" (5.69\%). According to the authors, if the model does not change, companies would continue to hide liabilities and assets in order to report higher income numbers and pay less income tax, as well as to report improved financial ratios.

Singh (2012) takes a sample of 234 restaurants and retail firms from years 2006 to 2008 and uses the constructive method. He analyzes 11 ratios related to interest coverage, leverage and profitability, and finds that they would change significantly for both sectors. The $\mathrm{D} / \mathrm{E}$ would increase more than three times, from 0.30 to 1.38 (354\%). Operating profit margins (EBITDA and EBIT) would also increase due to the removal of rent expense and its replacement with amortization and interest expense in different locations on the income statement. The return on invested capital (ROIC) ratio declined with an increase in debt in the denominator of the ratio, whereas the ROA ratio declined on an after-tax basis.

One of the most recent studies is that of Wong \& Joshi (2015). They focus on Australian quoted companies, using a sample of 107 companies from several different sectors using the constructive method. They find that financial ratios such as the D/E ratio, the D/A ratio and ROA would change significantly under lease capitalization. However, the change in ROE is insignificant. Total assets would increase by $3.47 \%$ and total liabilities would increase by $4.34 \%$. The $\mathrm{D} / \mathrm{E}$ ratio increases by 0.25 (31.49\% in relative terms); the D/A ratio increases by 0.46 (10.11\%); ROA decreases by $0.87 \%$ (15.35\%); and ROE decreases by $0.33 \%(1.23 \%)$. The comparison between positive and negative income subgroups shows different changes in the financial ratios, particularly in the $\mathrm{D} / \mathrm{E}$ ratio and ROA. Companies in the positive income sub-group present a higher increase in the $\mathrm{D} / \mathrm{E}$ ratio as compared to the negative income sub-group. Regarding the impact on ROA, the changes are different for the positive (decrease in ROA) and negative (increase in ROA) income sub-groups.

Finally, Morales and Zamora (2018) studied a sample of 646 European firms considering the final version of IFRS 16 . Using the methodology applied in this study, leverage, total assets and total liabilities would increase significantly while interest coverage would decrease. The sectors most affected were those for which the ratio of operating lease expense divided by total liabilities (lease intensity) was higher: retail, transportation, hotels, and software and services. In the case of the first three, this is due to the 'off-balance sheet' finance level they maintain, and in the case of software and services this is due to the small size on the balance sheet. 
Alternatively, a different line of research is that of value relevance, whereby authors analyze whether investors (capital or debt investors) use operating lease information to make their investment decisions. By way of example, Altamuro et al. (2014) analyze whether financial institutions evaluate the credit risk associated with operating leases. In the case of firms that do have an S\&P credit rating, they find no incremental explanatory power for the adjustment related to the capitalization of operating leases. They interpret this finding as evidence that lenders may proxy for the incremental risk effect of operating leases by using credit ratings which, as they also confirm, are adjusted for operating leases. However, credit ratings are not available for all companies. In the absence of a credit rating, they find evidence that bank loan spreads are better explained by financial ratios adjusted for the capitalization of operating leases. However, this result is concentrated on loans issued by larger lenders. Furthermore, they find evidence that the capitalization of operating leases that resemble true leases are less important when explaining loan spreads. More specifically, operating leases in the retail industry appear to be treated like rentals, whereas operating leases with residual value guarantees or with related parties are treated like liabilities. Finally, they find that operating lease adjustment is more prevalent when companies' bankruptcy risk is high.

Other recent line of research has been to find explanatory factors that predict the behavior of corporate groups with respect to the lease standard-setting process. Mellado y Parte, (2017) scrutinize the submission of comment letters by 306 non-financial listed companies in response to the discussion paper (DP 2009) and two exposure drafts (ED 2010 and ED 2013) elaborated jointly by the IASB and the FASB by distinguishing among three degrees of intensity in lobbying activities, depending on participation in the different discussion periods. Through a multivariate analysis, that shows the intensity of lobbying by considering participation in the three consultation periods, they find how this intensity of lobbying is associated with size, profitability, age, industry and managerial ownership.

With specific regard to Spanish firms, Fitó et al. (2013) analyze the relevance of the new lease standard's potential impact, and which companies will be most affected. They use data from 52 Spanish non-financial companies for the period from 2008 to 2010, and the constructive method is used (as in previous studies). They study both balance sheet ratios and performance ratios, and according to their results, leverage ratio (total liabilities/total equity + total liabilities) increases by 0.023 in absolute terms (34.48\% in relative terms); ROA decreases by 0.001 in absolute terms (3.7\% in relative terms); and ROE decreases by 0.047 in absolute terms ( $17.67 \%$ in relative terms). They find relevant changes in the leverage ratios, and also that performance ratios change, thereby concluding that the results do depend on the sector in question. The most affected sector is "retail services" (in which they include hotels and airlines - the most affected 
subsectors). Retail goods, energy and technology also have a relevant effect. Furthermore, they also conclude that size does not seem to be a significant variable for the analysis.

Another study which also focused on Spanish entities is that of Pardo et al. (2015), which uses data from all Ibex 35 companies for the period from 2010 to 2013. In their study analyzes, they use the constructive method. For discounting future cash flows, they use the discount rate used by the company for pensions and other provisions. Should this not be available, they use the median of the discount rates disclosed. Their results confirm that those firms which are more in debt and financially constrained use operating leases to a greater extent, which in turn suggests they will be more affected by the accounting change. They also find that larger firms and those that belong to the retail industry have more operating leases than others. In relation to ratios, they find that balance sheet ratios will be more affected than profitability ratios. Leverage (total liabilities/total assets) increases by $0.65 \%$ (in relative terms). ROA decreases by $2.15 \%$ (in relative terms).

In summary, previous studies show that the capitalization of operating leases will have a significant effect on the leverage, profitability and solvency metrics of companies. The dimension of the total balance sheet generally increases, and the leverage ratios show a higher leverage level. Profitability generally decreases using both ROA and ROE, and interest coverage ratios also decrease. These studies simulated capitalizations of leases prior to having the final version of the new lease accounting standard on Spanish companies. Moreover, these papers only consider minimum future lease payments as disclosed by companies in their financial statements (instead of total estimated payments, which can differ significantly), and neither do they use a discount rate that is consistent with factors such as maturity, the entity's credit risk or collateral coverage. Thus, we may construct our first hypothesis:

$H_{1}$ : The adoption of IFRS 16 will have a significant impact on balance sheet, profitability and solvency ratios of Spanish quoted companies.

Conversely, some sectors are more likely to use operating leases more extensively. As seen in the literature review, retail and hotels are the sectors most affected due to their use for real estate, and these sectors are very proactive in lobbying against a new accounting standard for leases. A further sector highly affected is transportation, since in many cases airplanes are leased. Hence, we propose our second hypothesis:

$\mathrm{H}_{2}$ : The adoption of IFRS 16 will have significant impact on leverage, profitability and solvency ratios depending on the sector in which the company operates. 


\section{METHODOLOGY}

\subsection{Lease asset and liability value estimation}

The methodology applied in this paper is closer to the factor method than to the constructive method. This is because we have not discounted minimum lease payments as disclosed in the entity's financial statements, but rather we have used a factor for each sector which is multiplied by the lease expense. The factor is a proxy of the estimated lease intensity of each sector.

We believe that the methodology previously applied by other authors (except for Morales and Zamora (2018)) could be improved because:

- Some works use minimum payments disclosed in the notes to the financial statements to estimate future lease payments. These payments may not constitute the best estimation of future lease payments under IFRS 16 since they only refer to the non-cancellable period. Lease payments under IFRS 16 may also include additional periods (covered by extension options).

- Other papers sometimes use a single discount rate for the whole sample (see, for example, Imhoff Jr. \& Lipe (1997)). In other cases, they use discount rates used by the companies in pensions and other provisions (Pardo et al., 2015), or even a 10-year Treasury bond rate or other "risk free rate", adding a spread depending on the company's credit quality (Fitó et al., 2013). None of the authors has simultaneously considered the credit quality of each company plus the value of the collateral represented by the leased asset.

- Other authors construct the leased asset under different models since IFRS 16 had not yet been issued. Finally, under the IFRS 16 model, the amortization of the lease asset (right-of-use) is generally linear (under Topic 842, it is not linear for operating leases).

In line with Morales and Zamora (2018), our methodology is based on selecting the most representative asset for each sector, and estimating its average expected lease term. We have taken the sale estimated lease term for each asset/sector. Subsequently, we create as many buckets of lease contracts as there are number of years included in the average lease term for the most representative asset. Each bucket has an annual payment equal to lease expense divided by the applied average lease term. Contracts in the first bucket started a number of years before current year equal to lease term, and ends on current year. Contracts in the second bucket started a number of years before current year equal to lease term plus one, and ends the following year, and so forth. Table 1 illustrates this concept for a company with a lease expense of 30 m.u. (monetary units), with an average lease term of 3 years and a discount rate of $10 \%$. 
Table 1

Calculation of the liability and asset book value

\begin{tabular}{|c|c|c|c|c|c|c|c|}
\hline YEARS & -3 & -2 & -1 & 0 & 1 & 2 & 3 \\
\hline $\begin{array}{r}\text { LEASE } \\
\text { PAYMENTS OF } \\
\text { BUCKET } 1\end{array}$ & 29.41 & 10 & 10 & 10 & & & \\
\hline $\begin{array}{r}\text { LEASE } \\
\text { PAYMENTS OF } \\
\text { BUCKET } 2\end{array}$ & & 29.41 & 10 & 10 & 10 & & \\
\hline $\begin{array}{r}\text { LEASE } \\
\text { PAYMENTS OF } \\
\text { BUCKET } 3\end{array}$ & & & 29.41 & 10 & 10 & 10 & \\
\hline $\begin{array}{r}\text { LEASE } \\
\text { PAYMENTS OF } \\
\text { BUCKET } 4\end{array}$ & & & & 29.41 & 10 & 10 & 10 \\
\hline & \multicolumn{3}{|c|}{$\begin{array}{l}\text { LIABILITY BOOK VALUE AT } \\
\text { THE END OF YEAR } 0 \\
\end{array}$} & 59.01 & 30 & 20 & 10 \\
\hline $\begin{array}{l}\text { BOOK VALUE } \\
\text { OF BUCKET } 1\end{array}$ & 29.41 & 22.06 & 14.70 & 7.35 & 0 & & \\
\hline $\begin{array}{l}\text { BOOK VALUE } \\
\text { OF BUCKET } 2\end{array}$ & & 29.41 & 22.06 & 14.70 & 7.35 & 0 & \\
\hline $\begin{array}{l}\text { BOOK VALUE } \\
\text { OF BUCKET } 3\end{array}$ & & & 29.41 & 22.06 & 14.70 & 7.35 & 0 \\
\hline \multirow[t]{2}{*}{$\begin{array}{l}\text { BOOK VALUE } \\
\text { OF BUCKET } 4\end{array}$} & & & & 29.41 & 22.06 & 14.70 & 7.35 \\
\hline & \multicolumn{3}{|c|}{$\begin{array}{l}\text { ASSET BOOK VALUE AT } \\
\text { THE END OF YEAR } 0\end{array}$} & 44.11 & & & \\
\hline
\end{tabular}

Source: Own elaboration.

Liability book value (59.01 m.u.) is the sum of the present value future cashflows of 3 lease contract buckets $(30,20,10)$. The value of the asset and liability related to each bucket at the beginning of its life (29.02) is the net present value of its cash-flows $(10,10,10)$. The asset is amortized in 4 years on a linear basis. The sum of the net book value of each value is equal to the total value of leased assets. In previous studies (Imhoff et al., 1991, 1997; Duke et al., 2009; Singh 2012, Wong \& Joshi, 2015; Morales-Díaz and Zamora-Ramírez, 2018), the asset value was assumed to be the same percentage of the lease liability for the whole sample, and this is not applicable when the buckets are set up as previously explained.

The interest rate implicit in the lease is proxied by the lessee's incremental borrowing rate. This discount rate must be adapted to the credit risk of the financial operation (a lease contract), taking into consideration company risk, the term of the contract and the leased asset. The leased asset must be considered because it guarantees the "lease loan" (i.e. it acts as a collateral). To take these concepts into account and to obtain the most precise discount rate for each company, our investigation proceeds in line with the work of Díaz and Zamora (2018).

Firstly, we obtain interest curves for each sector and rating, based on the current average Euro senior yields for several maturities (3 months to 30 years) 
for bonds issued by companies in a specific sector and with a specific public rating.

Secondly, given that previous curves are uncollateralized, the above interest curves are adapted to each asset/collateral by analyzing changes in a 5-year CDS spread when changing the Recovery Rate (R) parameter. We select a quoted CDS for a representative company in each of the abovementioned sectors, and we obtain the PD (Probability of Default); the CDS Spread; the Recovery Rate (generally 40\%); and sensitivity to the basis point (Sp01). We change the Recovery Rate, and to see how the CDS Spread changes maintaining the same PD, we use the following approximate formula:

$$
P D=\frac{S p 01}{(1-R)} \times \text { Spread }
$$

We apply the spread percentage change to the complete applicable yield curve: for example, if changing $\mathrm{R}$, the spread changes $-3 \%$ in relative terms, the whole curve is moved $-3 \%$ in relative terms. We also carry out the same exercise for several recovery rates depending on the leased goods. The recovery rates used are obtained from Hartmann-Wendels et al. (2014).

\subsection{Ratios analyzed}

We construct the hypothesis testing by comparing the mean of several ratios and metrics levels before and after operating lease capitalization (for the total sample and for each sector). In order to measure the relative variation of each ratio, comparability indexes are calculated using the following equation (Fitó et al., 2013):

$$
C_{i}=\left[\frac{R_{i}^{\prime}-R_{i}}{R_{i}}\right]
$$

where:

- $\mathrm{R}_{\mathrm{i}}^{\prime}$ is the financial ratio level after adopting IFRS 16 for company $i$.

- $\mathrm{R}_{\mathrm{i}}$ is the financial ratio level before adopting IFRS 16 for company $i$.

- $\mathrm{C}_{\mathrm{i}}$ is the comparability index for company $i$.

Since financial ratios do not generally follow a normal distribution (Fülbier et al., 2008; Fitó et al., 2013), whereas comparability indexes do so, the nonparametric Wilcoxon test is calculated for financial ratios, and the $t$-test is run for comparability indexes in order to test our hypothesis by comparing means.

As per Morales and Zamora (2018), we analyze six ratios and metrics divided into three groups: a) balance sheet/leverage; b) profitability; and c) interest coverage. Table 2 shows how all the ratios are calculated as well as the 
measurement of lease intensity. To calculate the effect on these ratios we use the effective tax rate.

\section{Table 2}

Ratios used

\begin{tabular}{|c|c|}
\hline Balance sheet ratios & Expression \\
\hline Increase in assets & ${\text { var. } . \text { Ass }_{i}}=\frac{\text { Assets }_{i}^{\prime}}{\text { Assets }_{i}}$ \\
\hline Increase in liabilities & ${\text { var. } \text { Liab }_{i}}=\frac{\text { Liabilities }_{i}^{\prime}}{\text { Liabilities }_{i}}$ \\
\hline $\begin{array}{l}\text { Lease expense on assets } \\
\quad \text { (lease intensity) }\end{array}$ & 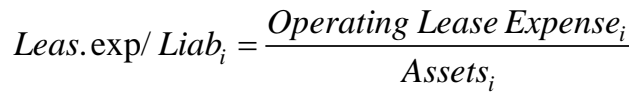 \\
\hline \multicolumn{2}{|l|}{ Leverage ratios } \\
\hline $\begin{array}{l}\text { Leverage on assets } \\
\text { before IFRS } 16 \text { adoption }\end{array}$ & $L A_{i}=\frac{\text { Liabilities }_{i}}{\text { Assets }_{i}}$ \\
\hline $\begin{array}{l}\text { Leverage on assets } \\
\text { after IFRS } 16 \text { adoption }\end{array}$ & $L A_{i}^{\prime}=\frac{\text { Liabilities }_{i}}{\text { Assets }_{i}^{\prime}}$ \\
\hline $\begin{array}{l}\text { Comparability index } \\
\text { of leverage on assets }\end{array}$ & $C I \cdot L A_{i}=\frac{L A_{i}^{\prime}-L A_{i}}{L A_{i}}$ \\
\hline \multicolumn{2}{|l|}{ Profitability ratios } \\
\hline ROA before IFRS 16 adoption & $R O A_{i}=\frac{E B I T_{i}}{\text { Assets }_{i}}$ \\
\hline ROA after IFRS 16 adoption & $\operatorname{ROA}_{i}=\frac{\operatorname{EBIT}_{i}^{\prime}}{\text { Assets }_{i}^{\prime}}$ \\
\hline Comparability index of ROA & CI.ROA $A_{i}=\frac{L A_{i}^{\prime}-L A_{i}}{L A_{i}}$ \\
\hline \multicolumn{2}{|l|}{ Coverage ratios } \\
\hline $\begin{array}{l}\text { Financial expenses coverage before } \\
\text { IFRS } 16 \text { adoption }\end{array}$ & $C O V_{i}=\frac{E B I T D A_{i}}{\operatorname{Int}_{E x x p}}$ \\
\hline $\begin{array}{l}\text { Financial expenses coverage after } \\
\text { IFRS } 16 \text { adoption }\end{array}$ & 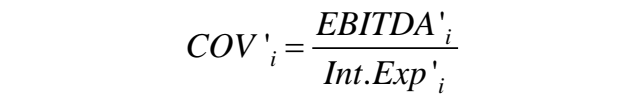 \\
\hline $\begin{array}{l}\text { Comparability index of coverage } \\
\text { of financial expenses coverage } \\
\text { after IFRS } 16 \text { adoption }\end{array}$ & $C I . C O V_{i}=\frac{C O V_{i}^{\prime}-C O V_{i}}{C O V_{i}}$ \\
\hline
\end{tabular}

Source: Own elaboration. 


\subsection{Data sources}

We have selected 101 Spanish firms included in the STOXX Total Market (Datastream mnemonic: LDJTMSTE). Financial statement data was extracted from Reuters and Worldscope, except for lease operating expenses that was collected manually. Discount rates were calculated using Bloomberg Euro interest rate curves per sector and rating (Bloomberg function: CRVF (Curve Finder)/CREDIT). We have used firm credit rates calculated by Reuters as they are available for all companies. The sample description and data sources are included in Table 3

Sample descriptionSector analysis was carried out based on 4-digit GICS (Global Industry Classification Standard).

Table 3

Sample description

\begin{tabular}{lr}
\hline \multicolumn{1}{c}{ Sector } & N \\
\hline Retail & 6 \\
Transport & 3 \\
Engineering & 5 \\
Pharmaceutical & 8 \\
Professional & 11 \\
Telecommunications & 3 \\
Media & 6 \\
Oil and Gas & 2 \\
Industrial & 27 \\
Power & 10 \\
Real Estate & 6 \\
Banks/Insurance & 7 \\
Construction & 5 \\
Hotels & 2 \\
\hline Constituents of STOXX Total Market & 101 \\
(Datastream mnemonic: LDJTMSTE) & \\
\hline
\end{tabular}

Source: Own elaboration.

\section{RESULTS}

Table 4 shows the mean, median (p50), standard deviation, minimum and maximum measures for all ratios as defined in Table 2. Wilcoxon tests were run for financial ratios because they do not follow a normal distribution, and t-tests run for comparability index ratios as they are normalized. Regarding variation of assets and liabilities, lease intensity and comparability indexes, these tests were carried out to control whether the means of variables were different from zero. In the case of leverage, ROA and coverage ratios, these statistical tests performed to control whether the mean after the adoption of IFRS 16 was different to the mean before the adoption of IFRS 16. 
In Table 4, we observe that assets and liabilities would increase by a mean of $12.9 \%$ and $28.5 \%$, with a maximum of $134 \%$ and $542 \%$ respectively. Compared with the study by Morales and Zamora (2018) of a European sample ${ }^{5}$, these results show a higher impact since they obtain means of $10 \%$ and $21.4 \%$ and maximum of $83.9 \%$ and $168 \%$. These results are also higher in comparison to previous studies (Durocher, 2008; Fülbier et al., 2008; Duke et al., 2009; Pardo et al., 2015; Wong \& Joshi 2015). Lease operating expense over assets is $1.8 \%$ (mean). Wilcolxon tests are significant at 99\% for these measurements.

Table 4

Statistics for full sample

\begin{tabular}{|c|c|c|c|c|c|c|c|c|}
\hline \multirow{2}{*}{ VARIABLES } & (1) & (2) & \multirow{2}{*}{$\begin{array}{c}(3) \\
\text { Wilcoxon } \\
p>|z|\end{array}$} & \multirow{2}{*}{$\begin{array}{c}(4) \\
\text { t-test } \\
\operatorname{Pr}(|T|>|t|) \\
\end{array}$} & \multirow{2}{*}{$\begin{array}{l}\text { (3) } \\
\text { p50 }\end{array}$} & \multirow{2}{*}{$\begin{array}{l}\text { (4) } \\
\text { sd }\end{array}$} & \multirow{2}{*}{$\begin{array}{l}(5) \\
\min \end{array}$} & \multirow{2}{*}{$\begin{array}{c}\text { (6) } \\
\max \end{array}$} \\
\hline & $\mathbf{N}$ & mean & & & & & & \\
\hline var.Ass & 101 & 0.129 & $\begin{array}{c}21.534^{\star \star \star} \\
(0.000)\end{array}$ & & 0.0375 & 0.245 & 0 & 1.342 \\
\hline var.Liab & 101 & 0.285 & $\begin{array}{c}20.675^{\star \star \star} \\
(0.000)\end{array}$ & & 0.0649 & 0.687 & 0 & 5.427 \\
\hline $\begin{array}{l}\text { Leas.expl } \\
\text { Total asset }\end{array}$ & 101 & 0.0183 & $\begin{array}{c}19.387^{\star \star \star} \\
(0.000)\end{array}$ & & 0.00603 & 0.0331 & 0 & 0.182 \\
\hline LA & 101 & 0.675 & $-21.62^{\star \star \star}$ & & 0.679 & 0.276 & 0.140 & 1.684 \\
\hline LA' & 101 & 0.719 & $(0.000)$ & & 0.718 & 0.259 & 0.189 & 1.665 \\
\hline CI.LA & 101 & 0.102 & & $\begin{array}{c}22.562^{\star \star \star} \\
(0.000) \\
\end{array}$ & 0.0250 & 0.233 & -0.0852 & 1.744 \\
\hline ROA & 101 & 18.20 & $-18.22^{\star \star \star}$ & & 0.286 & 137.2 & -0.809 & 1,352 \\
\hline ROA' & 101 & 10.25 & $(0.000)$ & & 0.272 & 63.04 & -0.799 & 617.8 \\
\hline CI.ROA & 101 & 0.0698 & & $\begin{array}{l}1.533^{\star} \\
(0.096) \\
\end{array}$ & -0.0167 & 0.597 & -0.654 & 3.870 \\
\hline COB & 101 & 65.24 & $16.223^{\star \star \star}$ & & 6.328 & 206.1 & -5.703 & 1,513 \\
\hline COB' & 101 & 25.12 & $(0.000)$ & & 6.368 & 74.27 & -5.571 & 654.6 \\
\hline CI.COB & 101 & -0.0889 & & $\begin{array}{c}6.549^{\star \star *} \\
(0.000)\end{array}$ & -0.00038 & 0.329 & -1.385 & 0.789 \\
\hline
\end{tabular}

Source: Own elaboration.

Leverage increases by $10.2 \%$, from a mean of $67.5 \%$ to $71.9 \%$, and is significant at $99 \%$. This means that the new liability that arising from new accounting rules for lease operations will have a high impact on Spanish companies' debt. These results are like those obtained for European companies. However, results for ROA are not so clear. The mean of return/profitability before and after IFRS 16 adoption decreases from $18.2 \%$ to $10.2 \%$, but does show an increase in its comparability index (6.9\%). We can also see how ROA has significant standard deviation, and that the significance of the comparability index is $90 \%$. In this sense, our results are similar to those of Morales and Zamora (2018) for European firms' return, and to those of Durocher (2008) who also uses EBIT over assets to measure profitability.

\footnotetext{
${ }^{5}$ Hereinafter, we are referring to this when considering European firms.
} 
About coverage, we see that the means decrease from 65 to 25, while the comparability index shows a decrease of $8.9 \%$, and both are significant at the 99\% level.

About the different sectors, Table 5 shows our main variables for each sector ordered by lease intensity (lease operating expense over total asset). The problem we encountered is that the samples per sector are very small, except in the case of the industrial sector. We have not included tests for mean signification for this reason. In general terms, we observe that the higher the lease intensity, the higher the impact on ratios.

Table 5

Statistics by sector

\begin{tabular}{lccccccc}
\hline & $\mathbf{N}$ & Leas.exp/ Tot. asset & var.Ass & var.Liab & Cl.LA & CI.ROA & Cl.COB \\
\hline Banks/Insurance & 7 & 0.0005 & 0.0043 & 0.0058 & 0.0014 & 0.4807 & 0.0024 \\
Real Estate & 6 & 0.0006 & 0.0044 & 0.0099 & 0.0054 & -0.0042 & 0.0019 \\
Power & 10 & 0.0042 & 0.0208 & 0.0258 & 0.0051 & 0.0218 & -0.0257 \\
Oil and Gas & 2 & 0.0043 & 0.0230 & 0.0450 & 0.0216 & 0.0016 & -0.0533 \\
Pharmaceutical & 8 & 0.0086 & 0.0664 & 0.2250 & 0.0461 & -0.0199 & -0.1550 \\
Industrial & 27 & 0.0086 & 0.0485 & 0.1174 & 0.0635 & 0.0068 & -0.0519 \\
Construction & 4 & 0.0111 & 0.0566 & 0.0833 & 0.0199 & 0.1358 & -0.1442 \\
Telecommunications & 3 & 0.0160 & 0.0949 & 0.1472 & 0.0445 & 1.2975 & -0.0996 \\
Engineering & 5 & 0.0178 & 0.1028 & 0.1718 & 0.0608 & -0.0645 & -0.1567 \\
Transport & 2 & 0.0186 & 0.1255 & 0.1847 & 0.0496 & 1.5897 & -0.4334 \\
Media & 6 & 0.0291 & 0.1987 & 0.3222 & 0.0958 & -0.0621 & -0.0989 \\
Professional & 11 & 0.0298 & 0.2157 & 0.2681 & 0.0514 & -0.1028 & -0.1511 \\
Hotels & 2 & 0.0754 & 0.6553 & 1.3516 & 0.4048 & -0.1857 & -0.5224 \\
Retail & 6 & 0.0992 & 0.7619 & 2.2536 & 0.7626 & -0.3701 & -0.5548 \\
\hline
\end{tabular}

Source: Own elaboration.

With specific regard to Spanish companies, like Morales and Zamora (2018) we also find that retail and hotels are the sectors most affected since they display the highest lease intensity ratios. This intensity is above the level of European firms, and results in an increase of more than $65 \%$ in assets and $135 \%$ in liabilities. This highly significant impact is also reflected in leverage, profitability and coverage. The sectors that experience the least impact are banks/insurance, real estate, power and utilities, which is consistent with the findings of the aforementioned European study.

Additionally, we see that ROA does not present a uniform and consistent result over the different sectors. Certain sectors experience a positive impact on their profitability (banks, telecommunications, transport) while for others the impact is extremely negative (retail, hotels, professional).

Table 5 also shows how the level of lease intensity is related to a deterioration in coverage, with transport, hotels and real estate - with a higher lease expense 
over assets ratio - being those sectors most affected. Certain other sectors - banks and real estate - do experience a positive impact but it is on a very minor level.

\section{CONCLUSION}

For the purposes of this study, we conduct an empirical analysis to determine the possible effect of IFRS 16 adoption on Spanish companies. Under this new standard, companies (lessees) will have to capitalize current operating leases. Previous literature has been studying the effect of this new standard on entities' balance sheet and profit and loss accounts since the lease accounting reform appeared on the horizon. However, there is no study that considers the final and definitive version of IFRS 16. This means that several parts of the methodology applied in previous literature needs to be improved: the estimation of lease term/payments (to consider not only the minimum lease payments); the discount rate (to consider the credit quality of the lessee and the recovery rate of the collateral); and the measurement of lease assets and liabilities.

The adoption of IFRS 16 will have a significant impact on the financial statements of Spanish firms, and it will be greater than its effect on European firms in those sectors most affected. There will be an impact on balance sheet due to the increase in assets and liabilities, involving an increase of leverage. These effects will be higher than that found previously in the literature, and specifically so in the case of European companies. However, the interest coverage ratio displays a considerable decrease. These effects are more profound in the more lease-intensive sectors such as retail, hotels, professional and the media.

Similarly, to previous studies, we are not able to present consistent results with regard to profitability. Certain sectors do experience an improvement in their ROA, but others are subject to a decrease in ROA. We have calculated the ROA ratio as EBIT divided by assets. When capitalizing operating leases, EBIT increases because there is no lease expense, and interest from lease liability is not included. However, assets also increase. For these reasons, the comparability index for ROA can present positive signs in certain sectors and negative signs in others.

This paper not only contributes to previous literature on the subject of the effects of lease capitalization, but it will also provide help to analysts and firms because it improves on how the capitalization of leases should be estimated. The methodology used is of benefit at present in terms of providing further information about the effects of IFRS 16 adoption on a specific firm or sector, and in the future, it will be of use for determining those effects in the first-time adoption of IFRSs by a firm. 


\section{BIBLIOGRAPHY REFERENCES}

ABDEL-KHALIK, A. R. (1981). "The Economic Effects on Lessees of FASB Statement No. 13". In Accounting for Leases. (FASB, Ed.). Stamford, Conn: FASB.

AICPA. (1994). "Improving Business Reporting - a Customer Focus: Meeting the Information Needs of Investors and Creditors: Comprehensive Report", pp. 1-140. Retrieved from http://www.aicpa.org/InterestAreas/FRC/AccountingFinancialReporting/ DownloadableDocuments/Jenkins Committee Report.pdf

ALTRAMURO, J., JOHNSTON, R., PANDIT, S., \& ZANG, H. (2014). "Operating Leases and Credit Assessments". Contemporary Accounting Research, 31(2), pp. 551-580. Available at: https://doi.org/10.1017/CBO9781107415324.004

BARONE, E., BIRT, J., \& MOYA, S. (2014). "Lease Accounting: A Review of Recent Literature". Accounting in Europe, 11(1), pp. 35-54. Available at: https://doi.org/10.1080/ 17449480.2014.903630

BEATTIE, V., GOODACRE, A., \& THOMSON, S. J. (2006). "International lease-accounting reform and economic consequences: The views of U.K. users and preparers". International Journal of Accounting. Available at: https://doi.org/10.1016/j.intacc.2005. 12.003

BEATTY, A., LIAO, S., \& WEBER, J. (2010). "Financial Reporting Quality, Private Information, Monitoring, and the Lease-versus-Buy Decision". The Accounting Review, 85(4), pp. 1215-1238. Available at: https://doi.org/10.2308/accr.2010.85.4.1215

BENNETT, B. K., \& BRADBURY, M. E. (2003). "Capitalizing Non-cancellable Operating Leases". Journal of International Financial Management and Accounting, 14(2), pp. 101-114.

BRYAN, S., LILIEN, S., \& MARTIN, D. (2010). "The financial statement effects of capitalizing operating leases". The CPA Journal. Retrieved from http://search.proquest.com/ openview/81f4a18dcdcc3fea943ffe2e39facb38/1?pq-origsite=gscholar

CORNAGGIA, K. R., FRANZEN, L., \& SIMIN, T. T. (2011). "Manipulating the Balance Sheet? Implications of Off-Balance-Sheet Lease Financing". SSRN Electronic Journal, (July). Available at: https://doi.org/10.2139/ssrn.1680077

DECHOW, P. M., GE, W., LARSON, C. R., \& SLOAN, R. G. (2011). "Predicting Material Accounting Misstatements". Contemporary Accounting Research, 28(1), pp. 17-82. Available at: https://doi.org/10.1111/j.1911-3846.2010.01041.x

DHALIWAL, D., LEE, H. S., \& NEAMTIU, M. (2011). "The Impact of Operating Leases on Firm Financial and Operating Risk". Journal of Accounting, Auditing \& Finance, 26(2), pp. 151-197. Available at: https://doi.org/10.1177/0148558X11401210

DUKE, J. C., HSIEH, S. J., \& SU, Y. (2009). "Operating and synthetic leases: Exploiting financial benefits in the post-Enron era". Advances in Accounting, 25(1), pp. 28-39. Available at: https://doi.org/10.1016/j.adiac.2009.03.001

DUROCHER, S. (2008). "Canadian Evidence on the Constructive Capitalization of Operating Leases". Accounting Perspectives, 7(3), pp. 227-256. Available at: https://doi.org/10.1506/ap.7.3.2

FASB. (1976). Statement of Financial Accounting Standards (SFAS) 13: Accounting for Leases. Norwalk.

FITÓ, M. A., MOYA, S., \& ORGAZ, N. (2013). "Considering the effects of operating lease capitalization on key financial ratios". Spanish Journal of Finance and Accounting / 
Revista Española de Financiación y Contabilidad, 42(159), pp. 341-369. Available at: https://doi.org/10.1080/02102412.2013.10779750

FÜLBIER, U. R., SILVA, J. L., \& PFERDEHIRT, H. M. (2008). "Impact of Lease Capitalization on Financial Ratios of Listed German Companies". Schmalenbach Business Review, 60(April), pp. 122-145.

GOODACRE, A. (2003). "Assessing the potential impact of lease accounting reform: a review of the empirical evidence". Journal of Property Research, 20(1), pp. 49-66. Available at: https://doi.org/10.1080/0959991032000051962

GROSSMAN, A. M., \& GROSSMAN, S. D. (2010). "Capitalizing Lease Payments". CPA Journal, 80(5), pp. 6-11. Retrieved from http://search.ebscohost.com.ezproxy.liv.ac.uk/ login. aspx?direct=true \&db=buh\&AN=54056280\&site=eds-live\&scope $=$ site $\% 5 C n$ http://content.ebscohost.com.ezproxy.liv.ac.uk/ContentServer.asp?T=P\&P=AN\&K=540 56280\&S=R\&D=buh\&EbscoContent=dGJyMNLe80Sep684zdnyOLCmrOqeqLBSs

IMHOFF JR., E. A, \& LIPE, R. C. (1991). "Operating Leases: Impact of Constructive Capitalization". Accounting Horizons, 5(1), pp. 51-63. Retrieved from http://search.ebscohost.com/login.aspx?direct=true $\& \mathrm{db}=$ buh $\& A N=9604010111 \&$ site $=e$ host-live

IMHOFF JR., E. A., \& LIPE, R. C. (1997). "Operating leases: Income effects of constructive capitalization". Accounting Horizons, 11(2), pp. 12-32. Retrieved from http://0search.proquest.com.fama.us.es/docview/208896121 ?accountid=14744

MELLADO, L., \& PARTE, L. (2017). "Determinantes corporativos de la intensidad del lobby en el proceso de elaboración de la norma de arrendamientos". Revista de Contabilidad, 20(2), 131-142. https://doi.org/10.1016/j.rcsar.2016.09.001

MOODY'S. (2015). Financial statement adjustments in the analysis of non-financial corporations.

MORALES-DÍAZ, J., \& ZAMORA-RAMÍREZ, C. (2018). "Effects of IFRS 16 on Key Financial Ratios: A New Methodological Approach". Accounting in Europe, 15(1), pp. 133. Available at: https://doi.org/10.1080/17449480.2018.1433307

MULFORD, C., \& GRAM, M. (2007). "The Effects of Lease Capitalization on Various Financial Measures: An Analysis of the Retail Industry". Journal of Applied Research in Accounting and Finance, 2(2), pp. 3-13.

PARDO F., GINER, B., \& CANCHO, R. (2015). "Operating Leases: An analysis of the economic reasons and the impact of capitalization on Ibex 35 companies". In Congreso AECA 2015 (pp. 1-5). Available at: https://doi.org/10.1007/s13398-014-0173-7.2

REITHER, C. L. (1998). "What are the best and the worst accounting standards?" Accounting Horizons.

SINGH, A. (2012). "Proposed Lease Accounting Changes: Implications for the Restaurant and Retail Industries". Journal of Hospitality \& Tourism Research, 36(3), pp. 335-365. Available at: https://doi.org/10.1177/1096348010388659

WONG, K., \& JOSHI, M. (2015). "The Impact of Lease Capitalisation on Financial Statements and Key Ratios: Evidence from Australia". Australasian Accounting, Business and Finance Journal, 9(3), pp. 27-44. Available at: https://doi.org/ 10.14453/aabfj.v9i3.3 
